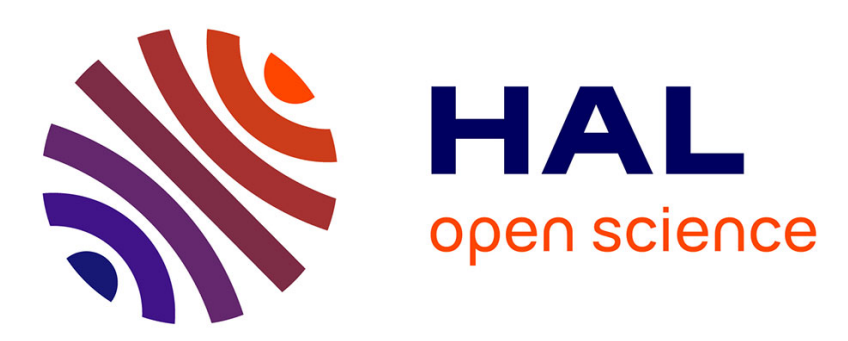

\title{
Relationship between the lipid compositions of marine aerosols, the sea surface microlayer, and subsurface water
}

Jean-Claude Marty, Alain Saliot, P. Buat-Ménard, R. Chesselet, K. A Hunter

\section{- To cite this version:}

Jean-Claude Marty, Alain Saliot, P. Buat-Ménard, R. Chesselet, K. A Hunter. Relationship between the lipid compositions of marine aerosols, the sea surface microlayer, and subsurface water. Journal of Geophysical Research, 1979, 84 (C9), pp.5707. 10.1029/JC084iC09p05707 . hal-03408966

\section{HAL Id: hal-03408966 https://hal.science/hal-03408966}

Submitted on 29 Oct 2021

HAL is a multi-disciplinary open access archive for the deposit and dissemination of scientific research documents, whether they are published or not. The documents may come from teaching and research institutions in France or abroad, or from public or private research centers.
L'archive ouverte pluridisciplinaire HAL, est destinée au dépôt et à la diffusion de documents scientifiques de niveau recherche, publiés ou non, émanant des établissements d'enseignement et de recherche français ou étrangers, des laboratoires publics ou privés. 


\title{
Relationship Between the Lipid Compositions of Marine Aerosols, the Sea Surface Microlayer, and Subsurface Water
}

\author{
J. C. MARTY AND A. SAliot
}

Laboratoire de Physique et Chimie Marine, ERA CNRS, Université Pierre et Marie Curie, 75230 Paris Cedex 05, France

\author{
P. Buat-Ménard, R. Chesselet, and K. A. Hunter ${ }^{1}$
}

Centre des Faibles Radioactivités, Laboratoire Mixte CNRS-CEA, 91190 Gif-sur-Yvette, France

\begin{abstract}
Aerosols, surface microlayer, and subsurface water samples have been collected during the "Midlante' cruise of the R/V Jean Charcot (May 1974) in the northeastern tropical Atlantic, taking all possible precautions against shipboard contamination. The concentrations of $n$ alkanes, total hydrocarbons, and fatty acids $\left(C_{12}\right.$ to $C_{32}$ were obtained by gas-liquid chromatography in these aerosol samples as well as for the dissolved and particulate fractions of the microlayer and subsurface waters. The aqueous phase fatty acids are of obvious planktonic origin, but an anthropogenic source cannot be definitely discounted for the aqueous phase $\boldsymbol{n}$ alkanes. On average, fatty acid lipids, $\boldsymbol{n}$ alkanes, and total hydrocarbons are all enriched in the microlayer by factors of $2-5$. The three aerosol samples show a strong similarity in composition, and all differ from the corresponding aqueous samples in having lauric acid $\mathbf{C}_{12}$ as the dominant acid instead of $\mathrm{C}_{16}$, typical of planktonic lipids, as found for the water samples. The hydrocarbon distributions of the aerosols, which resemble petroleum-derived materials, are characteristically different from those of the subsurface and microlayer, which are similar and appear to have a marine origin. The overlying $\boldsymbol{n}$ alkane distributions of all three sample types are similar, however, being generally regular without predominance of $n$ alkanes with $\boldsymbol{n}$ even or odd, and are also quite different from distributions characteristic of terrigenous dust containing hydrocarbons derived from higher plants.
\end{abstract}

\section{INTRODUCTION}

Simple lipids such as hydrocarbons and free or esterified fatty acids account for only a small part of the organic material that is present in the surface microlayer or which is transferred to and from the oceans [Hunter and Liss, 1977]. Nonetheless, owing to their chemical stability and the useful information that they can provide concerning their sources the joint study of these compounds in the marine aerosol and the microlayer may lead to useful knowledge of exchange processes at the air-sea interface. In spite of this consideration, available data are as yet rather limited. Duce et al. [1974] have measured gaseous hydrocarbons in the atmosphere, while the particulate fraction of the aerosol has been analyzed for hydrocarbons by Ketseredis et al. [1976] and Marty et al. [1978]. Only in the latter study were microlayer and bulk seawater samples collected at the same time. Simoneit [1977] and Simoneit and Eglinton [1975] have reported analyses of organic matter in aeolian dusts collected over the Atlantic.

Barger and Garrett $[1970,1976]$ have analyzed for fatty acid lipids in marine aerosols, noting the similarity of the fatty acid distributions found with those of microlayer and subsurface seawater samples from their other studies. The authors have argued that these atmospheric lipids are of essentially marine origin. A similar conclusion was reached by Quinn and Wade [1972] in the most complete study yet made. These authors analyzed for fatty acid lipids and hydrocarbons in aerosol, microlayer, and subsurface seawater samples collected during the same cruise in the North Atlantic. The data of the present paper are of a similar type and concern the detailed quantitative analysis of fatty acid lipids ranging from 12 to 32 car-

\footnotetext{
${ }^{1}$ Now at School of Environmental Sciences, University of East Anglia, Norwich NR4 7TJ, United Kingdom.
}

Copyright (c) 1979 by the American Geophysical Union. bon atoms in the marine aerosol, surface microlayer, and subsurface seawater samples collected in the eastern tropical Atlantic. Some data on the hydrocarbon composition of these samples are also presented.

\section{EXPERIMENTAL}

\section{Sampling}

Samples were obtained during the Midlante cruise of the R/V Jean Charcot in May 1974 (Figure 1). The atmospheric aerosol sample Al was collected along the cruise track denoted by the arrow in Figure 1, covering hydrographic stations 1 and 2. The other aerosol samples A2 and A3 were collected during small legs around station 4.

All three aerosol samples were taken by filtering large volumes (1200-1990 $\left.\mathrm{m}^{3}\right)$ of air through 15-cm diameter Whatman GF/B glass fiber filters in metal holders placed $8 \mathrm{~m}$ forward of the ship's bow and $8 \mathrm{~m}$ above sea level. According to the results of Duce et al. [1974], 95\% of total (gaseous plus particulate) hydrocarbons in the molecular size range $C_{14}$ to $C_{32}$ passed through this type of filter and were subsequently trapped as gaseous hydrocarbons on PVC plugs. Thus adsorption of gaseous hydrocarbons by GF/B filters appears to be negligible, and these compounds are collected mostly in the form of particulates. The pump was operated several meters behind the filter holders, minimizing contamination during head and cross winds. Wind direction was constantly monitored, and the pump was stopped manually each time there was a slight wind from the east. At no time was the pump in operation while the ship was sitting on station.

Water samples were collected at the beginning of each stop on a hydrographic station (Figure 1 , numbers 1-5) by using a rubber Zodiac boat $\mathbf{1 - 2} \mathrm{km}$ upwind of the ship. Subsurface water samples ( 100 l) were obtained by immersing a $25-1$ glass bottle several times about $20 \mathrm{~cm}$ below the water surface. Surface microlayer samples (20 l) were taken using the Garrett 


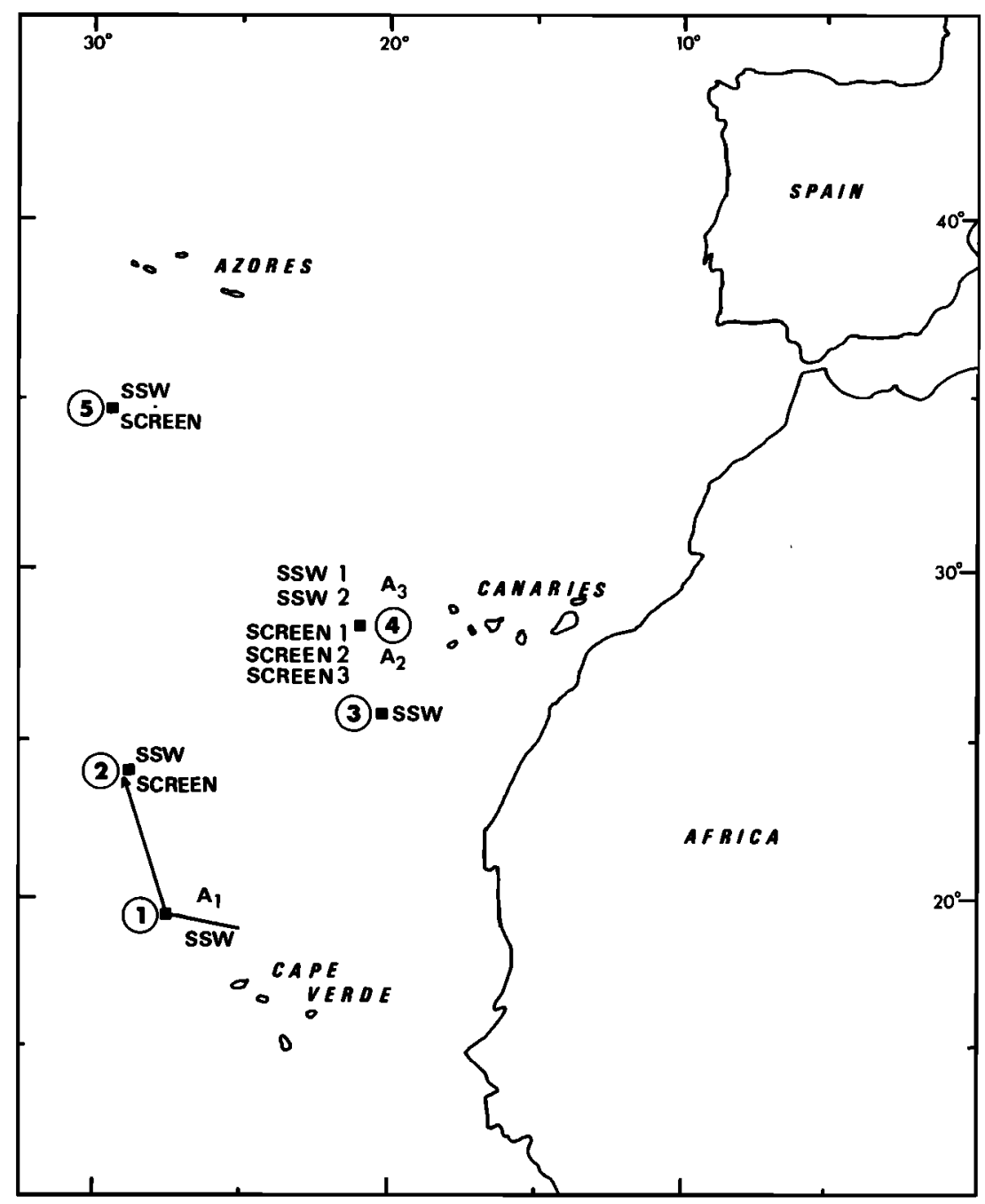

Fig. 1. Sampling sites. A1, A2, and A3 are aerosol samples, Screen refers to surface microlayer samples taken with the Garrett screen, and SSW denotes subsurface seawater sample. Numbers within circles refer to station numbers.

[1965] screen technique. A stainless steel screen made of 0.36 mm-diameter wire with 1.25 -mm-square openings in the mesh was immersed vertical to and removed horizontal to the water surface, sampling a water film approximately $0.44 \mathrm{~mm}$ thick [Marty, 1974]. The collected film was then drained into a glass sample bottle.

\section{FILTRATION OF MICROLAYER AND SUBSURFACE WATER SAMPLES}

Onboard ship, both microlayer and subsurface water samples were filtered through preextracted Whatman GF/C glass filters of 15-cm diameter. These filters collect particles with a diameter greater than $0.5-1.0 \mu \mathrm{m}$. Although this procedure only operationally defines the particulate fraction of the lipids in the water samples, the possibility that unesterified fatty acids in the dissolved state might adsorb strongly onto the polar glass fiber surface as a result of their own polar functional group COOH must be borne in mind. Saliot [1975] has shown from laboratory studies that the adsorption of $C_{15}$ and $C_{16}$ free fatty acids onto Whatman GF/C filters under conditions which resemble the present sample treatment amounts to 20 $25 \%$ of the dissolved acid concentration. This is likely to be an upper limit for the extent of adsorption of natural seawater fatty acid lipids, since neutral fatty acid esters probably do not adsorb so readily onto glass surfaces owing to their more nonpolar nature. According to the results of Garrett [1967] and Larsson et al. [1974], more than $70 \%$ of fatty acids in seawater and the surface microlayer are present in esterified form as triglycerides, steryl esters, and phospholipids. Where the amounts of total fatty acids found on the filter and in the filtrate are comparable, it seems fair to conclude that most of the fatty lipids retained by the filter are in particulate form.

\section{Extraction and Isolation of Hydrocarbons and Fatty Acids}

Dissolved lipids were extracted from the filtered water samples with chloroform [Barbier et al., 1973]. Glass fiber filters of the aerosol and seawater particulate matter samples were extracted immediately aboard ship for 24 hours in a Soxhlet apparatus using a 1:1 mixture of benzene and methanol. The lipid extracts were then treated to isolate fatty acids and hydrocarbons by the method described by Marty and Saliot [1976], saponification with $\mathrm{NaOH}$ under nitrogen, extraction of the unsaponifiable fraction (containing hydrocarbons) by 


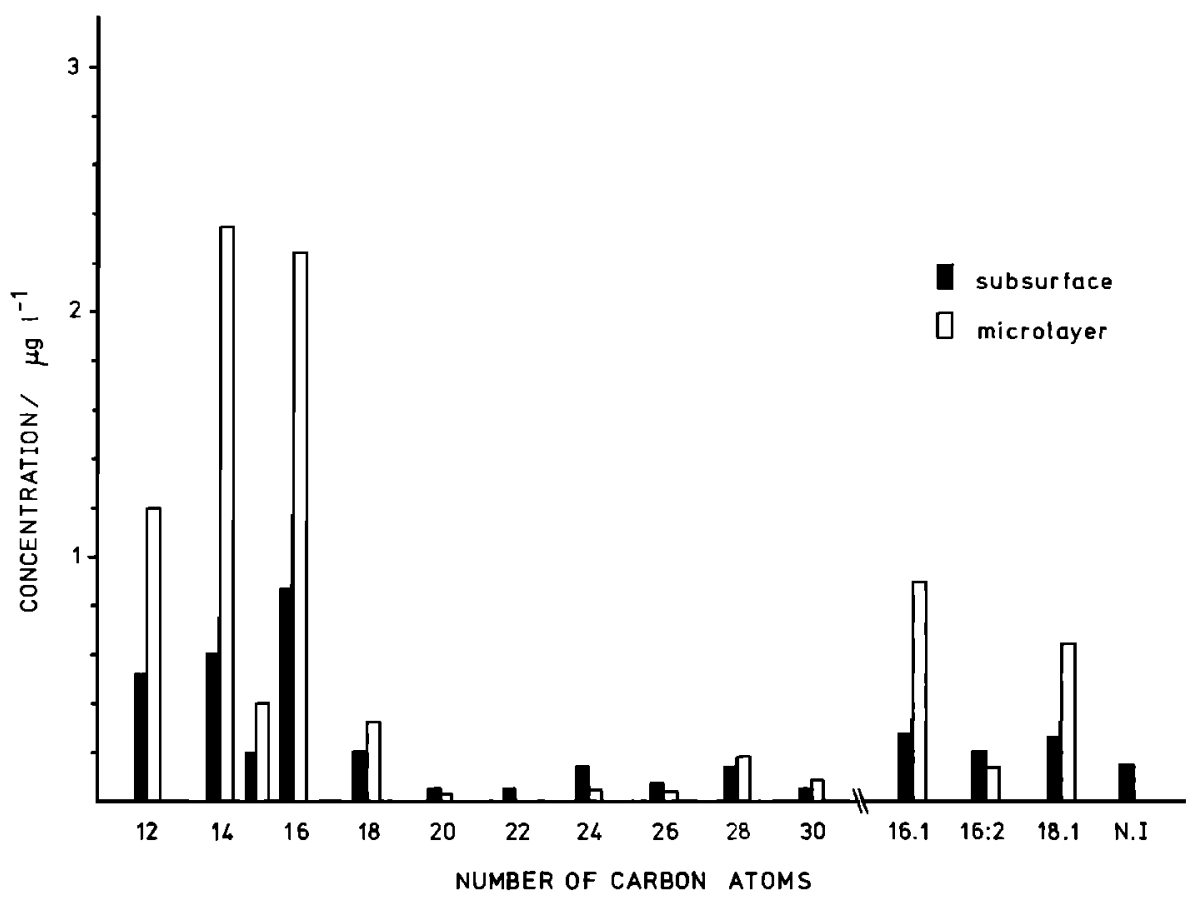

Fig. 2a. Fatty acid concentrations distributed with the number of carbon atoms (averaged results for stations 3,4 , and 5). Distribution on the left is for the $n$ carboxylic acids. Distribution on the right is for the unsaturated acids $\left(C_{n: m}\right.$, where $n$ $=$ number of carbon atoms and $m=$ number of double bonds) and for nonidentifiable peaks (N. I.). Figure shows dissolved fraction, microlayer samples (white bars), and subsurface water (solid bars).

ether acidification, and solvent extraction of the saponified acids by ether. The hydrocarbon extract was further purified by thin layer chromatography on silicic acid. The fatty acids were converted to their more volatile methyl esters by esterification with methanol using a $\mathrm{BF}_{3}$ catalyst, according to $\mathrm{Met}$ calfe and Schmitz [1961].

\section{Gas Chromatographic Analysis}

Analysis of fatty acid methyl esters was carried out on a Girdel $\mathbf{3 0 0 0}$ gas chromatograph using two different columns: (1) $10 \%$ diethyleneglycol succinate on $80 / 100$ mesh Chromosorb W HMDS, $2.5 \mathrm{~m}$ long and $3.2 \mathrm{~mm}$ ID, temperature pro-

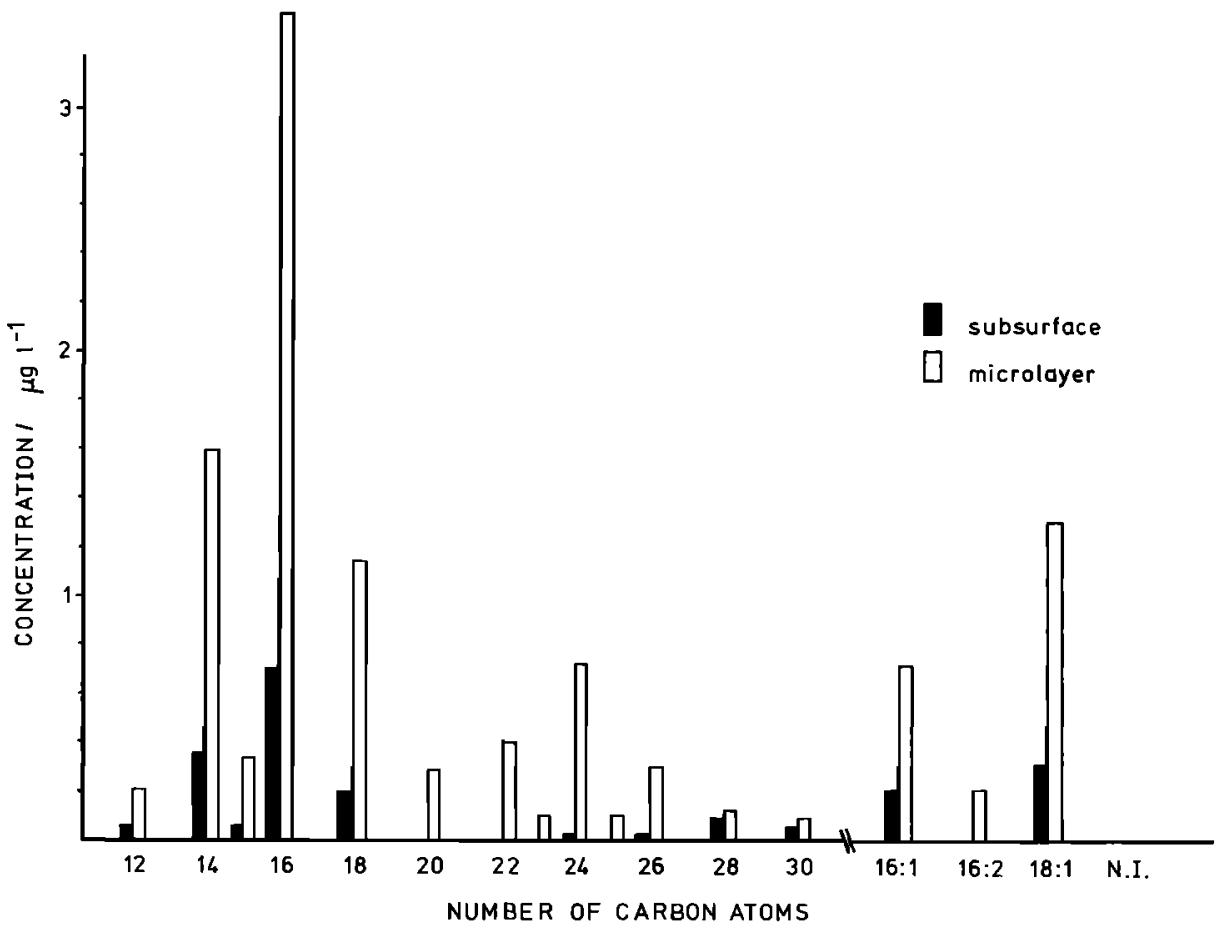

Fig. 2b. Same as for Figure 2a, but shows particulate fraction, microlayer samples (white bars), and subsurface water (solid bars). 


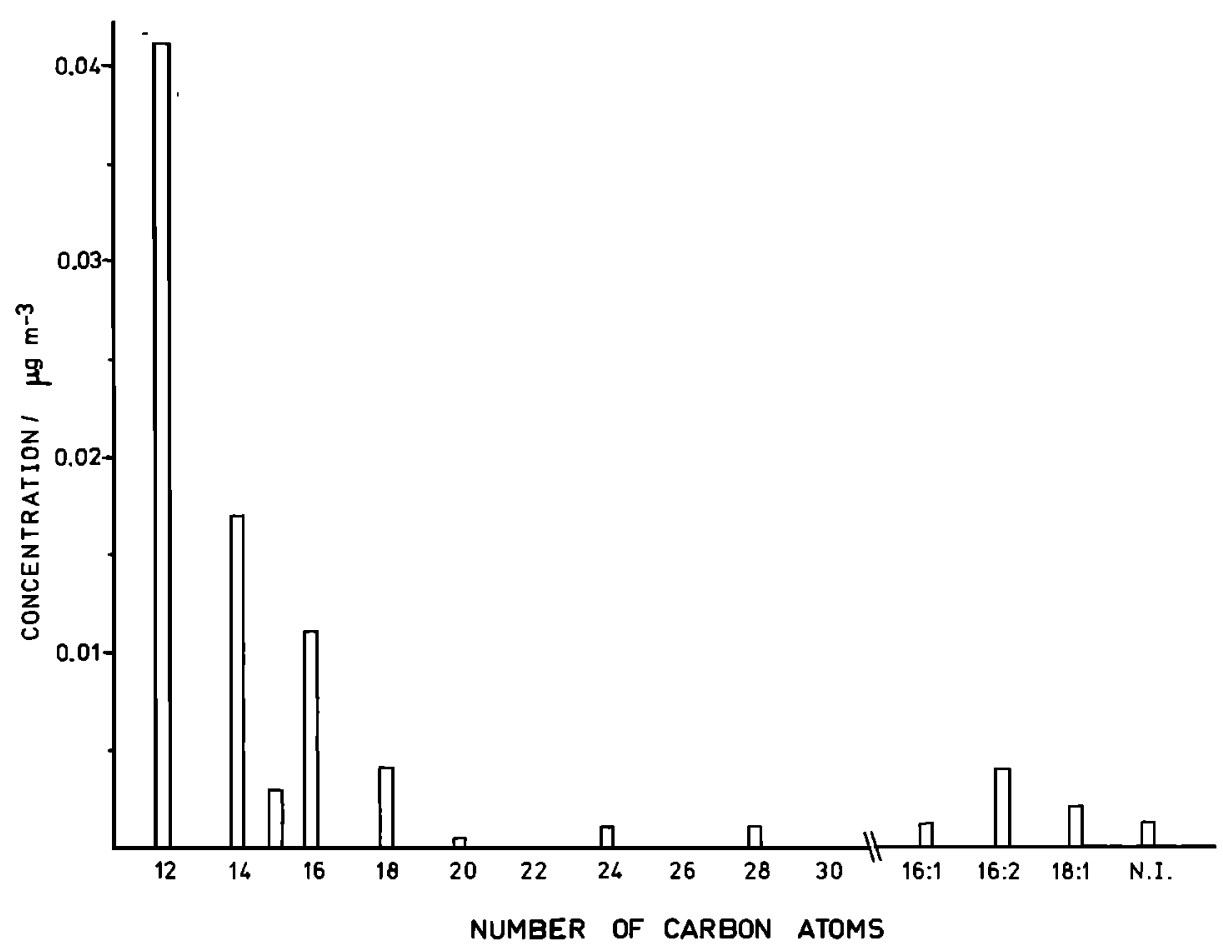

Fig. 2c. Same as for Figure 2a, but shows aerosol samples and average of A2 and A3 of station 4.

gramed from $150^{\circ} \mathrm{C}$ to $210^{\circ} \mathrm{C}$ at a rate of $3^{\circ} \mathrm{C} \mathrm{min}-1$, and (2) 1\% Dexsil on 80/100 mesh Gas Chrom Q, $4 \mathrm{~m}$ long and 3.2 $\mathrm{mm} \mathrm{ID}$, temperature programed from $150^{\circ} \mathrm{C}$ to $320^{\circ} \mathrm{C}$ at $6^{\circ} \mathrm{C}$ $\mathrm{min}^{-1}$. Fatty acid methyl esters were identified by comparison of the peak retention times with those of known standards on both columns. The peak area corresponding to each fatty acid ester was measured by means of a planimeter, and concentrations were obtained by comparison of sample peak areas with those of known amounts of standards run under the same analytical conditions.

Hydrocarbons were analyzed using the Dexsil column with a temperature program from $100^{\circ} \mathrm{C}$ to $300^{\circ} \mathrm{C}$ at a rate of $4^{\circ} \mathrm{C}$ $\min ^{-1}$. The $n$ alkanes were identified by comparison of their retention times with those of standard $n$ alkanes, and their concentrations were obtained as for the fatty acid esters by comparison of peak areas with those of known amounts of standards run under the same conditions. Unresolved peaks below the principal $\boldsymbol{n}$ alkanes formed an envelope (Figure 2) whose net area above the baseline was obtained by plan- imetry. The amount of total hydrocarbons represented by this envelope was calculated by assuming that the calibration factor for the hydrogen flame detector was the same as that of the $n$ alkane of comparable retention time.

\section{Blanks}

The GF/B glass fiber filters used for aerosol collection were not pretreated. Comprehensive aerosol blanks were taken by subjecting unused filters to the same conditions of storage, transport, and handling as the sample filters (except filtration of air), including mounting in the sample holder on the ship's bow. No hydrocarbon or fatty acid could be detected after analysis of these filters as described above.

\section{Precision and Limits of Detection}

The analytical precision, taking into account extraction, chemical steps during sample work-up, and the gas-liquid chromatography analysis has been estimated as $25 \%$ for fatty acids, $n$ alkanes, and total hydrocarbons. The corresponding

TABLE 1. Microlayer and Subsurface Waters

\begin{tabular}{|c|c|c|c|c|}
\hline \multirow[b]{2}{*}{ Station } & \multicolumn{2}{|c|}{ Fatty Acid, $\mu \mathrm{g} \mathrm{1}^{-1}$} & \multicolumn{2}{|c|}{ n Alkanes, $\mu \mathrm{g} \mathrm{^{-1 }}$} \\
\hline & Dissolved & Particulate & Dissolved & Particulate \\
\hline 1, subsurface & 37.54 & 2.10 & 3.05 & 0.20 \\
\hline 2, subsurface & 19.60 & 0.59 & ND & ND \\
\hline microlayer & 3.95 & 5.80 & ND & ND \\
\hline 3, subsurface & 4.93 & 3.69 & ND & ND \\
\hline 4 , subsurface 1 & 3.45 & 1.44 & 0.99 & 0.25 \\
\hline subsurface 2 & 2.00 & 1.26 & 0.24 & ND \\
\hline microlayer 1 & 5.82 & ND & 0.31 & 1.66 \\
\hline microlayer 2 & 10.45 & ND & 2.31 & ND \\
\hline microlayer 3 & 11.40 & 19.32 & 1.66 & 0.27 \\
\hline 5 , subsurface & 4.71 & 1.33 & ND & ND \\
\hline microlayer & 7.93 & 2.87 & ND & ND \\
\hline
\end{tabular}

Concentrations of fatty acids $\left(C_{12}\right.$ to $\left.C_{32}\right), n$ alkanes $\left(C_{14}\right.$ to $\left.C_{40}\right)$, and total hydrocarbons. Microlayer and subsurface water samples, dissolved and particulate fractions. ND indicates not determined. 
TABLE 2. Aerosol Samples

\begin{tabular}{cccc}
\hline Station & Sample & $\begin{array}{c}\text { Fatty Acid, } \\
\mu \mathrm{g} \mathrm{m}^{-3}\end{array}$ & $\begin{array}{c}n \text { Alkanes, } \\
\mu \mathrm{B} \mathrm{m} \mathrm{m}^{-3}\end{array}$ \\
\hline 1 & A1 & 0.23 & 0.05 \\
4 & A2 & 0.09 & 0.004 \\
4 & A3 & 0.08 & 0.03 \\
\hline
\end{tabular}

Concentrations of fatty acids $\left(C_{12}\right.$ to $\left.C_{32}\right), n$ alkanes $\left(C_{14}\right.$ to $\left.C_{40}\right)$, and total hydrocarbons.

limits of detection for these three components were as follows: (1) aerosols, $0.0001 \mu \mathrm{g} \mathrm{m}^{-3}$ (fatty acids), $0.00003 \mu \mathrm{g} \mathrm{m}^{-3}$ ( $n$ alkanes), $0.0003 \mu \mathrm{g} \mathrm{m}^{-3}$ (total hydrocarbons) and (2) water samples, $0.002 \mu \mathrm{g} \mathrm{1^{-1 }}$ (fatty acids), $0.001 \mu \mathrm{g} \mathrm{1^{-1 }}$ ( $n$ alkanes), 0.01 $\mu \mathrm{g}^{-1}$ (total hydrocarbons).

\section{RESULTS}

Table 1 shows the results from the Midlante cruise stations of Figure 1 , with $C_{12}$ to $C_{22}$ fatty acid concentrations and $C_{14}$ to $C_{40} n$ alkane concentrations in micrograms per liter for the dissolved and particulate fractions of subsurface seawater and surface microlayer samples. Aerosol concentrations are given in Table 2 in micrograms per cubic meter. The use in this work of external standards for the chromatographic analysis does not make allowance for any losses of individual fatty acids and $n$ alkanes during extraction and sample work-up. The data presented in the table are not corrected for losses of this kind which may have occurred. Garrett [1967], after comparing the distributions of free fatty acids in seawater and microlayer samples with those of saponified, methylated extracts of the total fatty lipids, concluded that the overall procedure (in particular the methylation step) may not be very quantitative for the lower molecular weight acids, e.g., below $\mathbf{C}_{14}$. An important fraction of these low-molecular-weight (MW) acids was found in the free fatty acid extracts. Some authors add to the original sample an internal standard comprising known quantities of one or two of the odd carbon number acids, e.g., $\mathrm{C}_{15}$ or $\mathrm{C}_{17}$, which occur at relatively minor levels in seawater samples [Quinn and Wade, 1972; Duce et al., 1972] in order to correct for losses during extraction of the sample and later work-up. It should be noted, however, that this form of internal standardization cannot correct properly for all losses in fatty acid lipids, since such losses depend critically upon the number of carbon atoms and upon whether the fatty acid is free or esterified. The evidence cited above suggests that in particular the recovery efficiencies of low-MW acids will be significantly lower than would be indicated by the use of $C_{15}$ or $\mathrm{C}_{17}$ as internal standards.

The concentrations observed in both water and aerosol samples vary over a wide range. It can be noted that the samples from stations 1 and 2, collected in rough seas during the first part of the cruise, are richer in fatty acids than stations 3 , 4, and 5, where calmer conditions prevailed. With such a limited amount of data, however, it is not possible to definitively ascribe the differences in fatty lipid concentrations to the sea conditions.

\section{Discussion}

\section{Hydrocarbons}

Comparison of the concentrations of microlayer and subsurface water hydrocarbons can only be made for station 4 , where it is seen that the microlayer is enriched in total hydrocarbons and $n$ alkanes by a factor of about 3-4. Enrichments of this magnitude or slightly smaller can also be seen in the results of Quinn and Wade [1972], Wade and Quinn [1975], and Marty and Saliot [1976] for both coastal and open ocean locations, including the wide variability in concentrations and enrichment. This variability seems to be a general characteristic of the microlayer [Barker and Zeitlin, 1972]. While such slight enrichments of up to 3 or 4 are typical of the microlayer under ambient surface conditions, in areas of obvious pollution by petroleum the surface film can be enriched many thousands of times with hydrocarbons as a result of multilayer oil films [e.g., Morris, 1974].

The $n$ alkanes represent 9,6 , and $2 \%$, respectively, of the total hydrocarbons of subsurface waters, the microlayer, and the aerosol (average results for station 4). This gradient could be explained by a selective accumulation of non $-n$ alkanes in the surface microlayer. In this connection, Ledet and Laester [1974] have found that cyclic and methyl-branched hydrocarbons are accumulated in this way, i.e., are a larger fraction of total hydrocarbons in the microlayer than in the subsurface water. The situation is not entirely clear, however, since Marty and Saliot [1976] found $n$ alkanes to be $15 \%$ of microlayer hydro-

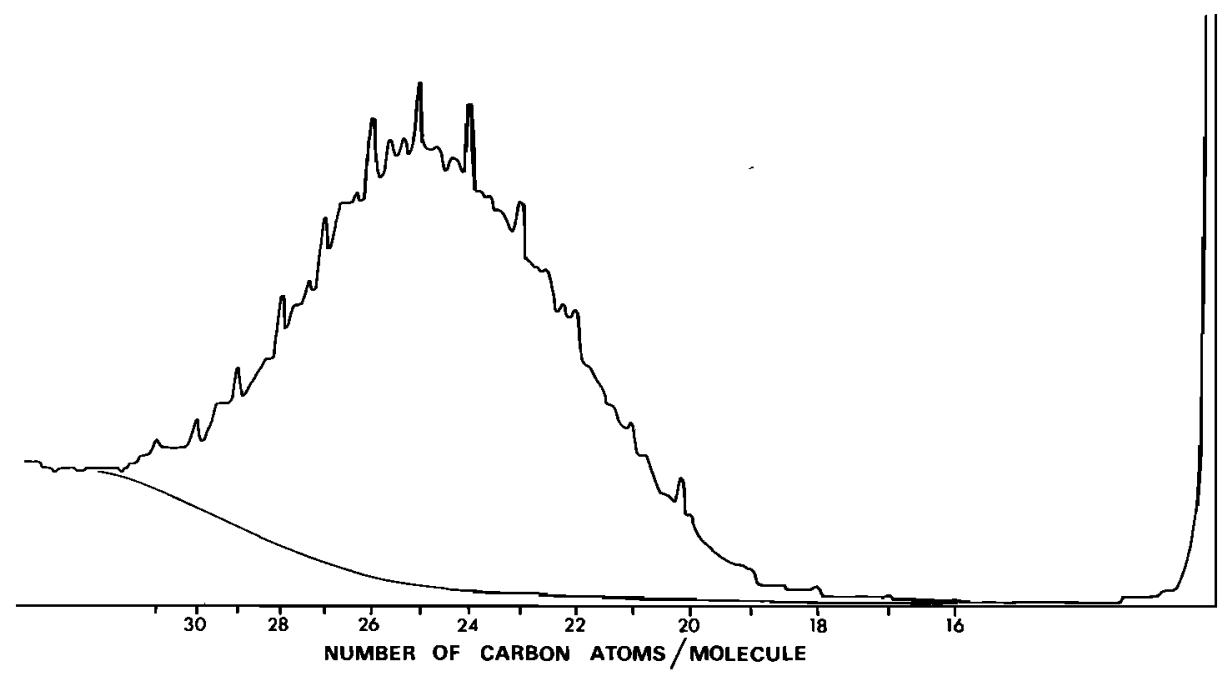

Fig. 3a. Gas chromatogram of hydrocarbon extracts illustrating the presence of $\boldsymbol{n}$ alkanes in aerosol sample A2. Numbers on the abscissa denote the numbers of hydrocarbon atoms in each $\boldsymbol{n}$ alkane at their positions in the chromatogram. 


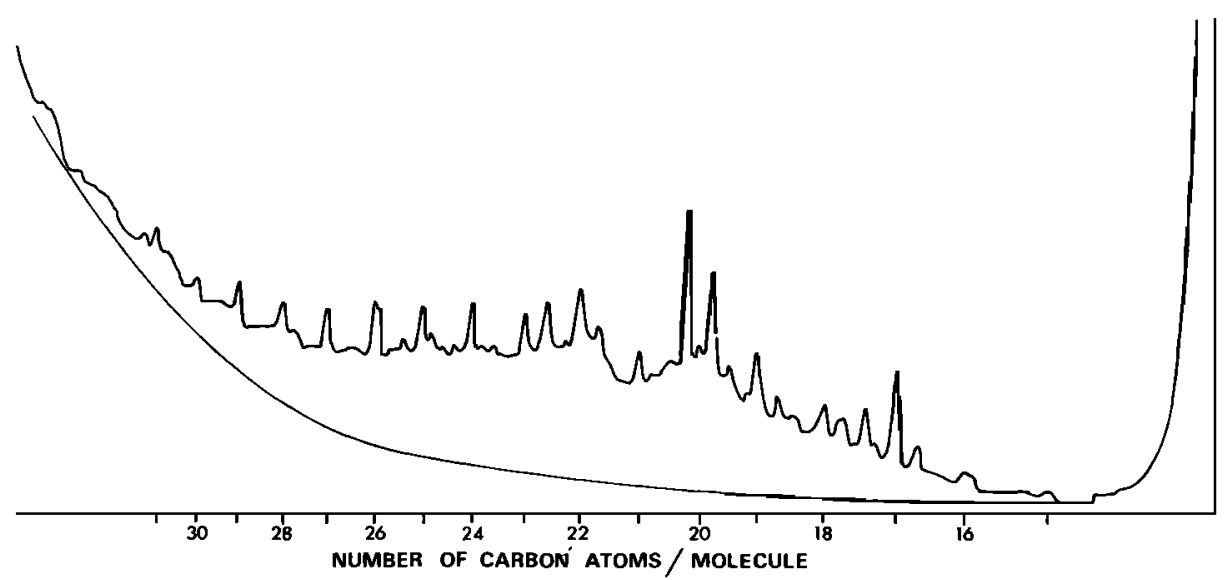

Fig. 3b. Gas chromatogram of hydrocarbon extracts illustrating the presence of $\boldsymbol{n}$ alkanes in subsurface water sample, station 4.

carbons at a variety of coastal and offshore sites, as opposed to only $10 \%$ for the subsurface waters. A detailed examination of these results or those of other workers suggests that the differences between microlayer samples manifested, for example, as enrichment of $\boldsymbol{n}$ alkanes or total hydrocarbons are not regular in nature. Few specific compounds show a consistent enrichment in the surface region for different sample pairs. It is therefore difficult to deduce the mechanisms of enrichment of the hydrocarbons in the microlayer, although it can be noted that there is no trend of increasing surface enrichment with carbon chain length such as might arise if there were decreasing solubility of hydrocarbons with size-controlled transport to the surface. Figure 3 shows typical chromatograms at station 4 for aerosol sample A2 (Figure 3a), dissolved phase hydrocarbons for the subsurface water (Figure $3 b$ ), and the microlayer (Figure $3 c$ ), illustrating the distribution pattern of $n$ alkanes superimposed on the 'hump' of unresolved hydrocarbons. No important differences in composition between the three aerosol samples or between the particulates of microlayer and subsurface water samples were found.

For the aerosol the unresolved hydrocarbon hump centered on about $\mathrm{C}_{25}$ is characteristically different from both of the aqueous phase chromatograms and resembles the patterns normally encountered with petroleum-derived materials such as tar balls [Butler et al., 1973]. The aqueous phase chromatograms, on the other hand, together with the regular distribu- tion of $\boldsymbol{n}$ alkanes without predominance of either even- or odd-numbered $n$ alkanes, are typical of those normally found in offshore, nonpolluted waters [Barbier et al., 1973; Marty and Saliot, 1976; Hardy et al., 1977] and could be attributed to natural marine sources [Clark and Blumer, 1967]. Petroleum materials also lead to a similar $\boldsymbol{n}$ alkane distribution, however, and in this respect, the $\boldsymbol{n}$ alkane pattern of the aerosols, despite the obvious differences in the major unresolved portion, is also regular without predominance of even- or odd-numbered $\boldsymbol{n}$ alkanes. This may only be a consequence of the petroleum origin of the aerosol hydrocarbons, but a possible marine source for the $n$ alkanes from bubble bursting in the microlayer cannot be ruled out. In this connection the proportion of resolved $n$ alkanes (2\%), which is low in comparison with the results of Duce et al. [1974] for gaseous and particulate hydrocarbons (20-25\%), may result from an important marine source diluted by the material in the large unresolved hump centered on $\mathrm{C}_{25}$. It must be added, however, that Duce et al. [1974] refer to all resolved hydrocarbons, which include a high proportion of non- $n$ alkanes [Quinn and Wade, 1972].

We do not find a predominance of the heavy $n$ alkanes $\left(C_{27}\right.$ to $\mathbf{C}_{33}$ ) with an odd number of carbon atoms usually observed in terrestrial higher plants [Douglas and Eglinton, 1966; Caldicott and Eglinton, 1973]. Such a predominance centered on $C_{27}$ was found by Simoneit [1977] in aeolian dusts collected during a cruise in the same region as that of the present study in

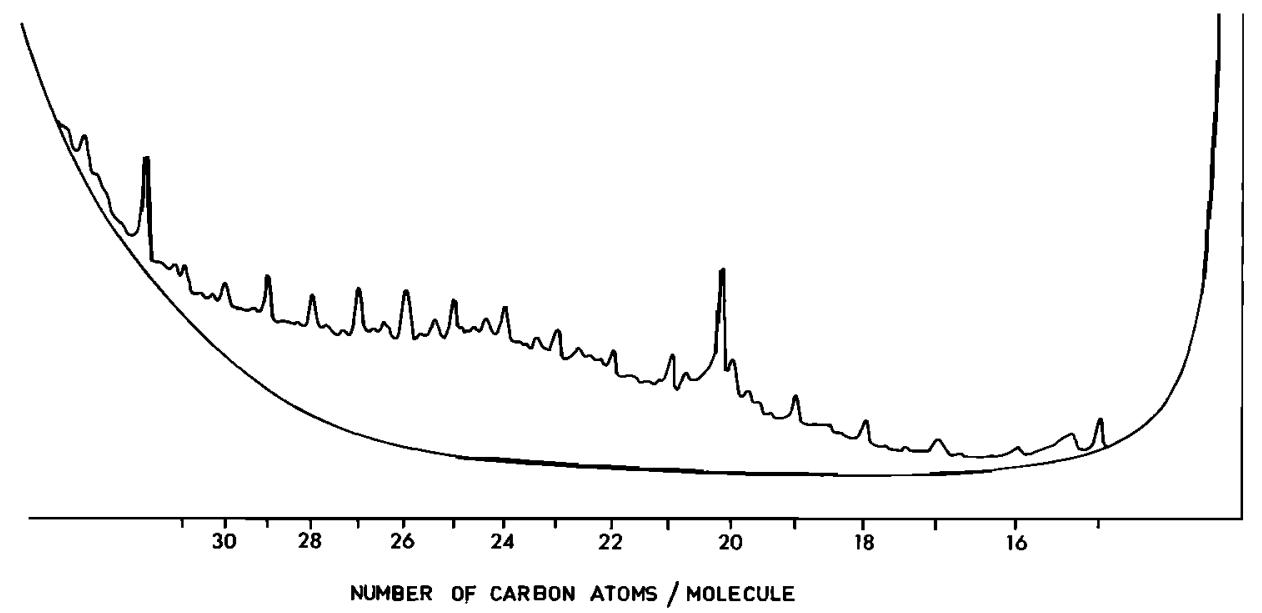

Fig. 3c. Gas chromatogram of hydrocarbon extracts illustrating the presence of $\boldsymbol{n}$ alkanes in the microlayer sample. 
April 1972. From these two results it is evident that the aerosol collected by air filtration differs quite considerably from the dust collected by net sampling [Simoneit, 1977], which contains an important terrestrial component. Indeed, from elemental analysis of aerosols collected on the same cruise as the present study [Chesselet et al., 1976; Buat-Ménard and Chesselet, 1979] it appears that the terrigenous component of the aerosol was only $6 \%$ by weight of the total salt.

The total hydrocarbon concentration in aerosol sample A2 falls in the same range as the results given by Duce et al. [1974] for Bermuda (2-4 $\mu \mathrm{g} \mathrm{m}^{-3}$, with $5 \%$ of this in particulate aerosol form and $95 \%$ gaseous), while the results for the other two aerosols are about an order of magnitude higher than at Bermuda. The data of Hoffman and Duce [1974] suggest an organic carbon (OC) aerosol concentration at Bermuda of $0.1-0.8 \mu \mathrm{g} \mathrm{m}^{-3}$, which indicates that hydrocarbons can be a major fraction of the aerosol organic matter. In fact a similar situation prevails in the area of the present study. Aerosol OC measurements made on the Rift (May-June 1974, Canaries-Dakar, 1.3-15.1 $\mu \mathrm{g} \mathrm{m}^{-3}$ ), Gate (July 1974, Cape Verde Islands, 0.66-2.5 $\mu \mathrm{g} \mathrm{m}^{-3}$ ), and Romancap (June 1977, Gulf of Guinea, $1.5-5 \mu \mathrm{g} \mathrm{m}^{-3}$ ) point to an average aerosol OC level in the area of $\sim 2 \mu \mathrm{g} \mathrm{m}^{-3}$ (P. Buat-Ménard, personal communication, 1978; J. C. Marty, unpublished manuscript, 1979) compared to an average hydrocarbon concentration of $1.4 \mu \mathrm{g} \mathrm{m}^{-3}$. The results obtained on the 1973 Meteor cruise in the north and eastern Atlantic [Ketseredis et al., 1976] are similar inasmuch as they can be compared with the present work: $0.5-2.0 \mu \mathrm{g} \mathrm{m}^{-3}$ of ether soluble organic matter in the aerosol, most of this being neutral compounds (which include hydrocarbons). Aerosol OC levels observed on this cruise vary between 0.5 and $1.5 \mu \mathrm{g} \mathrm{m}^{-3}$. Barger and Garrett $[1970,1976]$ find concentrations of $\mathrm{CHCl}_{3}$ soluble organic matter of $0.7-$ $6.3 \mu \mathrm{g} \mathrm{m}^{-3}$ in aerosols collected in Hawaii and $0.16-4.0 \mu \mathrm{g}$ $\mathrm{m}^{-3}$ in the eastern equatorial Pacific. Thus the present results are in agreement with previous studies made at similar sampling sites.

The apparent petroleum nature of the aerosol hydrocarbons and the small differences in composition of the three aerosols provide further support for the long-range transport in the atmosphere of anthropogenic hydrocarbon material, probably in the gas phase, which accounts for the bulk of hydrocarbon in the atmosphere [Duce et al., 1974], followed by gas-to-particle conversion over a wide geographical area, as discussed recently by Duce [1978]. This leads to a relatively constant aerosol composition with respect to organic components [Ketseredis et al., 1976] and relatively small variation in aerosol OC levels.

\section{Fatty Acid Lipids}

Total fatty acid concentrations (dissolved plus particulate) in the subsurface seawater samples are of the order of 3-9 $\mu \mathrm{g}$ $\mathrm{l}^{-1}$ for stations 3-5 (calm sea) and 20-40 $\mu \mathrm{g} \mathrm{I}^{-1}$ for stations 1 and 2 (rough sea). Most reported concentrations of total fatty

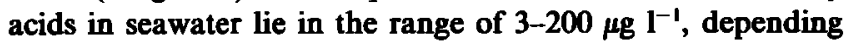
on the location and productivity of the water. Quinn and Wade [1972] found a geometric mean concentration of $33 \mu \mathrm{g}$ $1^{-1}$ total fatty acid for eight sites in the North Atlantic. Lower concentrations were found by Marty and Saliot [1974] at Roscoff, Brittany, and three Mediterranean stations between Nice and Corsica, although a small part of this difference is accountable by means of the internal and external standardization methods used by each respective group. At least half of the fatty acids found in the present study are in the dissolved fraction, while at stations 1 and 2 only a few percent of the fatty acids are found in the particulate fraction on the filter. By way of contrast, Marty and Saliot [1974] and Daumas et al. [1976] found the particulate fraction to be more important in coastal or shallow waters.

Figure 2 gives the mean distribution patterns with number of carbon atoms for stations 3,4 , and 5 , which are very similar. For both the microlayer and the subsurface samples, the distribution show characteristics typical of marine planktonic lipids: a high even-to-odd carbon number predominance and a carbon number range from $C_{12}$ to $C_{20}$, centered on about $C_{16}$ [Morris, 1974]. The heavy acids, $C_{22}$ to $C_{32}$, represent less than $3 \%$ of the total fatty acids, so the contribution of higher plan waxes having fatty acid distributions centered on $C_{24}$ to $C_{28}$ [Hitchcock and Nicholls, 1971] is relatively minor. This observation confirms the minor terrigenous contribution to the aerosol already discussed.

The combined results for the stations 3, 4, and 5 collected under similar sea conditions exhibit, as for hydrocarbons, an average enrichment of fatty acid lipids in the microlayer. For the dissolved fraction the mean concentration of fatty acid at these sites is a factor of 2.3 higher in the microlayer $(8.9 \mu \mathrm{g}$ $\left.1^{-1}\right)$ than in the subsurface water $\left(3.8 \mu \mathrm{g}^{-1}\right)$. An even greater enrichment factor of 5.8 is seen for the particulate fatty acids, with an average of $11.1 \mu \mathrm{g} 1^{-1}$ in the microlayer and of $1.9 \mu \mathrm{g}$ $\mathbf{1}^{-1}$ in the subsurface. Results of a similar nature have been obtained previously by Marty and Saliot [1974] and by Daumas et al. [1976]. The higher enrichment of particulate fatty acids may arise from their presence, even as traces, in the tissue lipids of surface neuston and in detrital particulate organic matter. The microlayer can be enriched by up to several orders of magnitude in the surface-dwelling organisms and neuston [Harvey, 1966; Liss, 1975], while it is well known that the enrichment of particulate organic carbon, which consists partly of tissue and cell detritus, is normally around 10 in comparison to subsurface water at offshore sites [Williams, 1967; Liss, 1975]. By contrast, the average microlayer enrichment of dissolved organic carbon is a factor of 2 or 3 [Williams, 1967; Sieburth et al., 1976]. The average results for the present study indicate an enrichment of total fatty acids (dissolved plus particulate) of the order of 3.5 , similar to values obtained by earlier workers [Quinn and Wade, 1972; Duce et al., 1972].

At station 2, where sea conditions were rough, dissolved fatty acids are considerably depleted in the microlayer (3.95 $\left.\mu \mathrm{g} 1^{-1}\right)$ in comparison to the subsurface water $\left(19.6 \mu \mathrm{g}^{-1}\right)$, while for the particulate fraction the microlayer is enriched by a factor of 10. This may be a lower limit for the enrichment factor for this sample, since it can be seen that the particulate fatty acid concentration in the subsurface water is only $3 \%$ of the dissolved fraction. Thus a significant portion of the 'particulate' acids found may in fact consist of dissolved lipids adsorbed onto the filter. For the other samples (except station 1), the dissolved and particulate levels are similar, so this problem is not so severe as discussed in the experimental section.

Such a striking difference in the partition of fatty acids between the dissolved and particulate fractions for microlayer and subsurface samples may arise from the production of particles at the surface (which flexes and folds the surface films). As far as the dissolved phase depletion is concerned, however, a more subtle explanation is called for. The microlayer sample collected by a Garrett screen has a typical thickness of several hundred micrometers, about 4 orders of magnitude greater 
than that of a typical simple lipid monolayer (2-4 nm, according to Adamson [1960]). It appears, according to a common sense way of thinking, to be a macroscopic layer of seawater. Thus increased mixing between the microlayer and the subsurface water $20 \mathrm{~cm}$ below brought about by turbulence in the water under rough conditions can reduce the concentration in an enriched microlayer to that of its much more massive subsurface layer but cannot lead to a depletion. In general, depletion in the microlayer must be explained either by the existence of a sink for microlayer components, e.g., active transport of surface components to the atmosphere, or by exchange between the surface region and subsurface water being incomplete; for example, a region of surface film is displaced in a horizontal direction by wind, wave action, and surface dilation into an unrelated region of subsurface water intrinsically richer in fatty acid lipids. This is in essence a form of resistant 'patchiness' at the surface and in the water column which is analogous to the 'sampling error' often referred to in the context of other studies such as of dissolved Fe in seawater [Strickland and Parsons, 1968]. This would be in accordance with other features of the data: the depletion of one or two specific fatty acids when most of the others and the total fatty acids are enriched (e.g., see $C_{24}$ and $C_{26}$ in Figure 2).

The fatty acid compositions of the aerosol samples are quite similar for the three samples, being characterized by the strong predominance of $C_{12}$ (lauric acid) over the $C_{16}$ acid found to be the most abundant in the aqueous samples. In the aerosols, lauric acid represents over $50 \%$ of all of the fatty acids present. This predominance of $C_{12}$ was not noticed by Ketseredis et al. [1976] and by Barger and Garrett [1976]. The results of Quinn and Wade [1972], on the other hand, reveal a much higher relative level of lauric acid in the aerosol than in microlayer and subsurface water samples collected during the same cruise and confirm the present work in this respect. However, lauric acid is never more than $23 \%$ of the total fatty acids in their samples. The different results of these studies may arise purely from critical differences in analysis methods for the low-MW acids such as reflux and distillation times for methyl esterification.

A tempting explanation of the increased abundance of the low-MW acid $C_{12}$ in the aerosol compared to the aqueous phase is that such low-MW acids (e.g., $C_{12}$ and $C_{14}$ ) are transported to the microlayer as rapidly as the other heavier acids but rapidly evaporate from the surface owing to their greater volatility and later condense onto aerosol particles in the atmosphere. The concentration of fatty acid lipids in the marine aerosol and in the microlayer for such a hypothetical transport scheme would therefore result from a balance of fluxes in and out. In particular for the aerosol, fatty acids could arise both from the evaporation and condensation on aerosol particles as well as from the production by bubble bursting in the microlayer of an aerosol enriched in fatty acids. Thus the relative amounts of different acids may vary with chain length in a way quite different from that in the aqueous phase.

It is difficult to model the evaporation of the fatty lipids from the sea surface because the exact esterified forms of the acids are not known. The approximate ratios of the equilibrium vapor pressures of $C_{12}, C_{14}, C_{16}$, and $C_{18}$ free acids are $10: 4: 2.5: 1$, while for the more volatile methyl esters the vapor pressures of the $C_{12}, C_{14}$, and $C_{16}$ esters are in the ratios of 10:2.5:1 [Schlessinger, 1971]. Little appears to be known of the vapor pressure of triglyceride esters, but they are clearly less volatile than the two forms already mentioned.
According to the evaporative flux model of Brimblecombe and Hunter [1977], which has been applied to volatile organic species such as DDT, the steady state concentration of evaporated material in the aerosol after condensation will be proportional to the equilibrium vapor pressure. If therefore the evaporating species in seawater is the free acid (after hydrolysis of esters), we might expect approximately $10 / 2.5=4$ times as much $\mathrm{C}_{12}$ in the aerosol as $\mathrm{C}_{16}$ in comparison to their relative amounts in the water. From the data of Figure 2 it can be calculated that the observed ratio is only twice as great, using the concentrations of $C_{12}$ and $C_{16}$ in the aerosol and the dissolved fraction of the microlayer (the latter seems more appropriate than total fatty acids for an evaporative model). A greater difference between the predicted evaporative flux of $C_{12}$ and $C_{16}$ free acids would be expected if the free $C_{12}$ acid concentration were actually much higher than the value of Figure 2 as a result of loss of low-MW acids during analysis. As mentioned earlier, Garrett [1967] has experimental evidence that low-MW free acids $\left(<\mathrm{C}_{12}\right)$ are important in seawater and microlayer samples and are underestimated by the usual extraction/esterfication methods. Thus taking proper account of the uncertainties in such a simple explanation, it seems that evaporation/recondensation of light acids may account in part for the shift in fatty acid distribution from aqueous phase to the aerosol observed in the present study and warrants further investigation. An essential feature of any future work of this type and of fatty acid lipid analyses in general must be a comprehensive examination of recovery efficiencies as a function of chain length and esterified forms, especially for low-MW acids.

An approximate idea of the enrichment of fatty acid lipids in the aerosol which results from the above two transport processes from the microlayer to the atmosphere can be gained by calculating the aerosol enrichment factor $(E F)$ with respect to $\mathrm{Na}$ [Duce et al., 1972]. The average aerosol Na concentration in the area of the present study is $\sim 3 \mu \mathrm{g} \mathrm{m}^{-3}$ [BuatMenard and Chesselet, 1979], which together with the aerosol and seawater fatty acid concentrations of Tables 1 and 2 indicates that the aerosol is enriched in fatty acids in relation to the surface water by $E F \sim 5-9 \times 10^{4}$. Total sea salt and aerosol fatty acid concentrations given by Barger and Garrett [1970] for Hawaii are consistent with this result for subsurface water concentrations of the order of $10-20 \mu \mathrm{g} \mathrm{l}^{-1}$, i.e., at the lower end of the range normally observed in seawater.

\section{ConClusions}

Fatty acid lipids, total hydrocarbons, and $n$ alkanes are enriched in the surface microlayer of the eastern tropical Atlantic in agreement with numerous other studies. The fatty acids have an obvious origin in planktonic lipid material, and, while this is also the probable type of source for the aqueous phase hydrocarbons and $n$ alkanes as well, input of anthropogenic hydrocarbons with a regular $n$ alkanes series is also partly consistent with the distribution patterns found. The aerosol has a distinctly different pattern of total hydrocarbons that closely resembles typical petroleum materials such as tar balls. This and the close similarity in composition of the different aerosol samples appear to provide evidence for long-range transport of anthropogenic hydrocarbons in the major gaseous form followed by gas-to-particle conversion in the atmosphere. The aerosols are completely different in $\boldsymbol{n}$ alkane and hydrocarbon distribution from large-particle, aeolian dust samples collected in the area of the present study by other 
workers [Simoneit, 1977]. This difference also appears consistent with the gas-to-particle conversion process, which should place the condensed hydrocarbon species into the small-particle end of the aerosol size spectrum, as is observed for aerosol OC [Duce, 1978].

The pattern of fatty acid lipids in the aerosol does resemble, however, the planktonic distribution found in the aqueous subsurface and microlayer samples except for one striking and important difference. Low-MW acids, in particular lauric or dodecanoic acid $C_{12}$, become important constituents of the aerosol. Crude model calculations suggest that the volatility differences between subsequent members of the homologous series of free fatty acids are sufficient to account for this relative fractionation simply by evaporation from the microlayer of low-MW free fatty acids. This proposed mechanism is thought to be superimposed on transport of microlayer material to the atmosphere as a result of bubble bursting [MacIntyre, 1968]. Owing to the experimental difficulties which plague analyses of low-MW fatty acid lipids the evaporative process may be considerably more important than previously thought. Considerably more work will be required before the complex exchange processes and dynamics of the sea surface microlayer are properly understood.

Acknowledgments. We should like to thank W. D. Garrett and P. S. Liss for their helpful advice and comments on the manuscript. K.A.H. is indebted to the Royal Society of London for financial assistance in the form of an European Exchange Programme Fellowship.

\section{REFERENCES}

Adamson, A. W., The Physical Chemistry of Surfaces, 629 pp., John Wiley, New York, 1960.

Barbier, M., D. Joly, A. Saliot, and D. Tourres, Hydrocarbons from seawater, Deep Sea Res., 20, 305-314, 1973.

Barger, W. R., and W. D. Garrett, Surface active organic material in the marine atmosphere, J. Geophys. Res., 75, 4561-4566, 1970.

Barger, W. R., and W. D. Garrett, Surface active organic material in the air over the Mediterranean and over the eastem equatorial Pacific, J. Geophys. Res., 81, 3151-3157, 1976.

Barker, D. R., and H. Zeitlin, Metal ion concentrations in the sea surface microlayer and size-separated atmospheric aerosol samples in Hawaii, J. Geophys. Res., 77, 5076-5086, 1972.

Brimblecombe, P., and $\mathbf{K}$. A. Hunter, Rock volatility and aerosol composition, Nature, 265, 761-762, 1977.

Buat-Ménard, P., and R. Chesselet, Variable influence of the atmospheric flux on the trace metal chemistry of oceanic suspended matter, Earth Planet. Sci. Lett., 42, 399-411, 1979.

Butler, J. N., B. F. Morris, and J. Sass, Pelagic tar from Bermuda and the Sargasso Sea, Spec. Publ. 10, Bermuda Biol. Sta., Bermuda, 1973.

Caldicott, A. B., and G. Eglinton, Surface waxes, in Phytochemistry III: Inorganic elements and special groups of chemicals, edited by $\mathbf{L}$. P. Miller, pp. 162-194, Van Nostrand Rheinhold, New York, 1973.

Chesselet, R., R. A. Duce, and D. C. Blanchard, International symposium on the chemistry of sea-air particulate exchange processes, J. Rech. Atmos., 8, 501-1006, 1974.

Chesselet, R., P. Buat-Ménard, M. Lesty, and C. C. Jehanno, Heavy metals in oceanic microlayer derived aerosols, Joint Oceanographic Assembly Book of Abstracts, Food and Agricultural Organization of the United Nations, Rome, 1976.

Clark, R. C., Jr., and M. Blumer, Distribution of $n$-paraffins in marine organisms and sediment, Limnol. Oceanogr., 12, 79-87, 1967.

Daumas, R. A., P. L. Laborde, J. C. Marty, and A. Saliot, Influence of sampling method on the chemical composition of water surface films, Limnol. Oceanogr., 21, 319-326, 1976.

Douglas, A. G., and G. Eglinton, The distribution of $\boldsymbol{n}$ alkanes, in Comparative Phytochemistry, edited by T. Swain, pp. 57-77, Academic, New York, 1966.

Duce, R. A., Speculations on the budget of particulate and vapor phase nonmethane organic carbon in the global troposphere, Pure Appl. Geophys., 116, 244-273, 1978.

Duce, R. A., J. G. Quinn, C. E. Olney, S. R. Piotrowicz, B. J. Ray, and T. L. Wade, Enrichment of heavy metals and organic compounds in the surface microlayer of Narragansett Bay, Rhode Island, Science, 176, 161-163, 1972.

Duce, R. A., J. G. Quinn, and T. L. Wade, Residence time of nonmethane hydrocarbons in the atmosphere, Mar. Pollut. Bull., 5, 59, 1974.

Garrett, W. D., Collection of slick-forming materials from the sea surface, Limnol. Oceanogr., 10, 602-605, 1965.

Garrett, W. D., The organic chemical composition of the ocean surface, Deep Sea Res., 14, 221-227, 1967.

Hardy, R., P. R. Mackie, K. J. Whittle, and R. A. A. Blackman, Occurence of hydrocarbons in the surface film, sub-surface water and sediment in the waters around the United Kingdom, Rapp. Proces. Verb. Reunions Cons. Perma. Int. Explor. Mer, 171, 61-65, 1977.

Harvey, G., Microlayer collection from the sea surface: A new method and initial results, Limnol. Oceanogr., 11, 608-614, 1966.

Hitchcock, C., and B. W. Nicholls, Plant Lipid Biochemistry, Academic, New York, 1971.

Hoffman, E. J., and R. A. Duce, The organic carbon content of marine aerosols collected on Bermuda, J. Geophys. Res., 79, 4474, 1974.

Hoffman, G. L., R. A. Duce, P. R. Walsh, E. J. Hoffman, B. J. Ray, and J. L. Fasching, Residence time of some particulate trace metals in the oceanic surface microlayer: Significance of atmospheric deposition, J. Rech. Atmos., 8, 745-759, 1974.

Hunter, K. A., and P. S. Liss, The input of organic material to the oceans: Air-sea interactions and the organic chemical composition of the sea surface, Mar. Chem., 5, 361-379, 1977.

Ketseredis, G., J. Hahn, R. Jaenicke, and C. Junge, The organic constituents of atmospheric particulate matter, Atmos. Environ., 10, 603-610, 1976.

Larsson, K., G. Odham, and A. Sodergren, On simple lipid surface films on the sea, I, A simple method for sampling and studies of composition, Mar. Chem., 2, 49-57, 1974.

Ledet, E. J., and J. L. Laseter, Alkanes at the air-sea interface from offshore Louisiana and Florida, Science, 186, 261-269, 1974.

Liss, P. S., The chemistry of the sea surface microlayer, in Chemical Oceanography, edited by J. P. Riley and G. Skirrow, Pp. 193-243, Academic, New York, 1975.

MacIntyre, F., Bubbles: A boundary layer microtome for micronthick samples of a water surface, J. Phys. Chem., 72, 589-592, 1968.

Marty, J. C., Contribution a l'etude de la pellicule ultrasuperficielle des octans: Atténuation de l'ultraviolet, composition en acides gras et en hydrocarbures, Thèse $3 e$ Cycle, 77 pp., Université de Paris, 1974.

Marty, J. C., and A. Saliot, Etude chimique comparee du film de surface et de l'eau de mer sous-jacente: Acides gras, J. Rech. Atmos., 8, 563-570, 1974.

Marty, J. C., and A. Saliot, Hydrocarbons (normal alkanes) in the sea surface microlayer of seawater, Deep Sea Res., 23, 863-873, 1976.

Marty, J. C., A. Saliot, and M. J. Tissier, Inventaire, répartition et origine des hydrocarbures aliphatiques et polyaromatiques dans l'eau de mer, la microcouche de surface et les aérosols marins en Atlantique tropical Est, C. R. Acad. Sci. Ser. D, 286, 833-836, 1978.

Metcalfe, L. D., and A. A. Schmitz, The rapid preparation of fatty acid esters for gas chromatographic analysis, Anal. Chem., 33, 363364, 1961.

Morris, R. J., Lipid composition of surface films and zooplankton from the eastern Mediterranean, Mar. Pollut. Bull., 5, 105-109, 1974.

Quinn, J. G., and T. L. Wade, Lipid measurements in the marine atmosphere and the sea surface microlayer, in Baseline Studies of Pollutants in the Marine Environment, edited by E. D. Goldberg, pp. 633-663, National Science Foundation, Washington, D.C., 1972.

Saliot, A., Acides gras, sterols et hydrocarbures en milieu marin: Inventaire, applications géochimiques et biologiques, Thèse d'état, 167 pp., Université Pierre et Marie Curie, Paris, 1975.

Schlessinger, G. G., Vapor pressures, critical temperatures and critical pressures of organic compounds, in Handbook of Chemistry and Physics, edited by R. C. Weast, pp. 146-172, Chemical Rubber Company, Cleveland, Ohio, 197!!

Sieburth, J. McN., P. Willis, K. M. Johnson, C. M. Burney, D. M. Lavoie, K. R. Hinga, D. A. Caron, F. W. French, P. W. Johnson, and P. G. Davis, Dissolved organic matter and heterotrophic mi- 
croneuston in the surface microlayers of the North Atlantic, Science, 194, 1415-1418, 1976.

Simoneit, B. R. T., Organic matter in aeolian dusts over the Atlantic Ocean, Mar. Chem., 5, 443-464, 1977.

Simoneit, B. R. T., and G. Eglinton, Organic matter in aeolian dus and its input to marine sediments, in Advances in Organic Geochemistry, edited by R. Campos and J. Goni, pp. 415-430, Enadimsa, Madrid, 1975.

Strickland, J. D. H., and T. R. Parsons, A practical handbook of seawater analysis, Bull. 167, 311 pp., Fish. Res. Board of Canada, Ottawa, 1968.
Wade, T. L., and J. G. Quinn, Hydrocarbons in the Sargasso Sea surface microlayer, Mar. Pollut. Bull., 6, 54-57, 1975.

Williams, P. M., Sea surface chemistry: Organic carbon, nitrogen and phosphorus in surface films and subsurface waters, Deep Sea Res., 14, 791-800, 1967

(Received August 1, 1978 revised March 1, 1979; accepted March 19, 1979.) 